\title{
Experimental Phenomenology and the Need for Psychology to Reconnect with its Philosophical Origins
}

\section{Chris Krägeloh $^{1}$}

Published online: 7 May 2020

(C) Springer Science+Business Media, LLC, part of Springer Nature 2020
The present paper responds to Lundh (2019) and other phenomenological thought that has been applied to mindfulness research through proposals to use phenomenological methods to study the experiences associated with mindfulness and meditation practice. I have previously commented on the inadequacy of phenomenological inquiry in the context of nondual awareness (Krägeloh 2019). As nondual awareness refers to pre-reflective experience and is commonly understood in the context of the Buddhist philosophy of emptiness, the phenomenological process of working up a structure or a co-generated essence of experience results in an objectification of nondual awareness and thus places it within the domain of language and concepts. Certainly, nondual awareness is only a very specific phenomenon that has been discussed in the mindfulness research literature, and Lundh's (2019) proposal for an experimental phenomenology applies to a much broader range of mindfulness-related experiences. Nevertheless, philosophical reflections such as the ones I presented in relation to nondual awareness (Krägeloh 2019) will continue to be relevant here, particularly since the techniques used in mindfulness-based interventions have originally been adapted from Buddhist traditions where philosophical reflection, meditation, and experience are intertwined (Sayrak 2019). Even if the secularized mindfulness practices are considered purely from the scientific perspective of Western psychology, Lundh's (2019) proposal to study experience in terms of independent and dependent variables and to provide so-called fine-grained descriptions requires that experience be clearly defined. Lundh's (2019) article reveals psychology's more recent tendency to shy away from philosophical discussion, including in the mindfulness literature (Krägeloh et al.

Chris Krägeloh

chris.krageloh@aut.ac.nz

1 Department of Psychology and Neuroscience, School of Clinical Sciences, Faculty of Health and Environmental Sciences, Auckland University of Technology, Auckland 1142, New Zealand
2019). Below, I briefly highlight how experimental phenomenology is linked to the early literature on introspection and how the philosophical considerations at that time continue to be relevant.

\section{Introspection and Experience}

Lundh (2019) has already presented a comprehensive overview of phenomenology that I do not need to repeat here in detail. Some of the more recent developments of this approach, including the experimental phenomenology proposed by Lundh (2019), focus on experience at increasingly finegrained levels. This is in contrast with some of the perhaps more traditional phenomenological research that tends to refer to Edmund Husserl's work when outlining a recommended analysis approach. Depraz et al. (2003), for example, proposed a "disciplined practical approach to exploring human experience" (p. 1). Here, experience is studied through systematic steps starting with suspension of judgement by the interviewer and eventually arriving at co-generated descriptive categories that are intended to capture the structure and essence of the experience of interest. When discussing the application of this approach to nondual awareness (Krägeloh 2019), I argued that such a phenomenological approach promotes joint (researcher and participant) reflections on experience, which should be described as an interaction with experience within a socio-cultural domain. Although Lundh (2019) did not provide an outline of any recommended data analysis processes, it appears that the more micro-level nature of experimental phenomenology may involve a lesser degree of cogeneration of a supposed essence and instead takes participant reports more at face value. Irrespective of the social validity or the eventual scientific utility of this approach, the unit of analysis remains linguistic.

Around the same time period when Edmund Husserl published his work on phenomenology, the concept of experience also played an important role in the newly established 
discipline of psychology. What was different, however, was that the focus of interest was predominantly on raw experience as opposed to its abstracted content. In Grundriss der Psychologie, Wilhelm Wundt (1897) defined psychology as the science of unmediated experience (unmittelbare Erfahrung), which he conceptualized as a constellation of processes as opposed to objects of inert content. The purpose of psychology was to investigate experience as it presents itself in its unmediated form and how it may be connected to other experiences. The natural sciences explore objects as abstracted from the subject and thus in terms of content that is mediated by experience, and Wundt (1897) viewed psychology as supplementary to the natural sciences, although psychology should still employ scientific methods. In this context, Wundt (1897) discussed the methods of observation and experimental manipulation but argued that observation is not suitable for a science of immediate experience as it would require an a priori ability to delineate the start and finish of experiential appearances and thus treat them as inert objects. Only experimental manipulation would enable research to break down complex experiences into its various component processes.

A major difference between the experimental method described by Wundt (1897) and that of experimental phenomenology (Lundh 2019) is that the former focused on immediate experience while the latter concerns the documentation of phenomena after some mediation through language has already occurred. In terms of how Wundt (1897) defined experience, experimental phenomenology (Lundh 2019) may be more described as exploring psychological constructs and not experience directly. Psychological constructs are compounds of immediate experience that have been abstracted into independent units. Although experimental phenomenology may justifiably claim to provide a more fine-grained analysis of linguistic units than traditional phenomenology, it remains at the level of what Wundt (1897) would have described as a Geisteswissenschaft (humanities) — of which he considered psychology to be the foundation.

My sketch of the early literature on immediate experience is only meant to be brief, but I would at least like to mention the work by some of the other theorists whose work is also relevant here. Within the German-language literature, notable scholars include Oswald Külpe and Richard Avenarius (Krauss 2017). Oswald Külpe was a student of Wilhelm Wundt who later broke away and initiated what was later called the Würzburg School of introspection (Hackert and Weger 2018). Unlike Wundt's approach, which focused on basic elements of tightly defined conscious experience, the Würzburg School widened the scope to include higher-order cognitive functions. The methods used in their approach have been described as similar to those of phenomenology (Hackert and Weger 2018), and the experimental nature of the introspection practiced by the Würzburg School may arguably mean that any differences are even less noticeable when comparing them to experimental phenomenology. In the absence of explicit mention of the assumed ontological nature of experience in experimental phenomenology (e.g. Lundh 2019), readers may need to rely on references to philosophers such as Husserl. Alternatively, experimental phenomenology may decide to follow the path of the Würzburg School and remain ontologically agnostic. Without committing to whether psychological phenomena are to be placed within monistic or dualistic ontological frameworks, Külpe (1893) stated that the goal of his empirical psychology was to provide a complete description of the characteristics of experiences as dependent on experiencing individuals. In this context, experiences were defined as the most fundamental data that form the object of reflection but that are themselves pre-reflective.

Similar to Külpe, Avenarius initially worked closely with Wundt but later diverged in his thinking to the point that they distanced themselves from each other (Krauss 2017). In Kritik der reinen Erfahrung, Avenarius (1888) explained that a fundamental assumption of all human beings is that they are located in surroundings consisting of manifold components, that there are other individuals who can utter manifold kinds of statements, and that statements or predications are in some kind of dependence by the person's surroundings. This applies to knowledge generation in science just as much as in nonscientific situations. Experience is thus what presents itself when the environment provides the determining conditions for statements, and here the act of stating would also be an experience. In this context, pure experience was defined by Avenarius (1888) as experience in terms of predications (what is said or das Ausgesagte) that is only determined by the surroundings and with no other experiences mixed in. In other words, these are raw experiences that do not include further reflection or elaboration after they had arisen in the determining environment. Avenarius called his philosophy empiriocriticism as it has its starting point that everything is experience but then proceeds to investigating to what extent experience that is valid for an individual is also universally valid, such as socially agreed on (Carstanjen 1897). In terms of ontology, empiriocriticism is neither materialism nor idealism as the environment is neither taken as phenomena or appearances nor as real or true, since any such claims are only worked up through reflection after the initial raw experiences.

Published around the same time as empiriocriticism and subsequently more widely known is the philosophy of radical empiricism by William James (1904a). Like Avenarius and Külpe (Krauss 2017), James took experience as the starting point but was even more explicit about its ontological role, calling it the "primal stuff or material in the world" (p.478, James 1904b). Being primal, it does not consist of anything and is simply the collective name for all that appears. Distinctions such as between inner and outer (in relation to individuals) or between fact and opinion only emerge when 
pre-reflective pure experience is elaborated on through additional experiences. Similar to Avenarius (1888), who considered the context of other speakers as crucial, James (1904c) referred to the so-called conterminousness of different minds in order to avoid solipsism or the exclusive focus on only one's own consciousness. This concern thus mirrors that noted for introspection in the recognition that theories of psychological processes would not be possible without linguistic means and thus the consideration of statements from other people (Krauss 2017). Of course, this raises the issue of whether a fully first-person science is even possible.

\section{Conclusion}

I do not wish to challenge the potential social validity and utility of experimental phenomenology, and as Lundh (2019) stated, conclusions drawn from studies following this approach are meant to be hypothetical and provisional. However, I am also using this opportunity here to highlight the fact that modern developments in the study of experience do not engage in philosophical thought to nearly the same depth in which it was embedded within the early days of psychology. The history of the concept of experience in psychology and philosophy is far too rich for it not to be leading to misunderstandings and contradictions unless the intended meaning of the term is explicitly stated.

In regard to experimental phenomenology, I would argue that the so-called fine-grained view of experience is more likely to deal with immediate and even pure experience as opposed to the more extended experience that is the topic of co-generation in typical phenomenological studies. Therefore, extending the scope of phenomenology to such micro-level experience will likely encounter the same limitations that I outlined for the study of nondual awareness (Krägeloh 2019). However, given Lundh's (2018) previous work on ontology, it is likely that we will see further refinement of experimental phenomenology in terms of application of philosophical theories, which I would also encourage for psychology as a discipline more broadly. This does not necessarily require a commitment to a particular ontological view and may proceed in a similar manner to which contextual behavioural science is explicitly a-ontological (Herbert and Padovani 2015). But with no detailed description of what is meant by experience, any attempt to provide fine-grained accounts of it will be difficult to compare with other related research. In the mindfulness literature, where concepts such as bare attention implicate the need to make distinctions between pre-reflective and interpretative experience (Bodhi 2011), this level of detail is even more important.

\section{References}

Avenarius, R. (1888). Kritik der reinen Erfahrung [Critic of pure experience]. Retrieved from https://archive.org/details/ kritikderreinen00avengoog/mode/2up . Accessed 4 May 2020.

Bodhi, B. (2011). What does mindfulness really mean? A canonical perspective. Contemporary Buddhism, 12(1), 19-39. https://doi.org/10. 1080/14639947.2011.564813.

Carstanjen, F. (1897). Richard Avenarius and his general theory of knowledge, empiriocriticism. Mind, 6(4), 449-475. https://doi.org/10. 1093/mind/VI.4.449.

Depraz, N., Varela, F. J., \& Vermersch, P. (Eds.). (2003). On becoming aware: a pragmatics of experiencing. John Benjamins Publishing Company.

Hackert, B., \& Weger, U. (2018). Introspection and the Würzburg school - implications for experimental psychology today. European Psychologist, 23(3), 217-232. https://doi.org/10.1027/1016-9040/ a000329.

Herbert, J. D., \& Padovani, F. (2015). Contextualism, psychological science, and the question of ontology. Journal of Contextual Behavioral Science, 4, 225-230. https://doi.org/10.1016/j.jcbs. 2014.11.005.

James, W. (1904a). A world of pure experience. I. Journal of Philosophy, Psychology, and Scientific Methods, 1(20), 533-543. https://doi.org/ 10.2307/2011912.

James, W. (1904b). Does 'consciousness' exist? Journal of Philosophy, Psychology, and Scientific Methods, 1(18), 477-491. https://doi.org/ 10.2307/2011942.

James, W. (1904c). A world of pure experience. II. Journal of Philosophy, Psychology, and Scientific Methods, 1(21), 561-570. https://doi.org/ 10.2307/2011356.

Krägeloh, C. U. (2019). Phenomenological research fails to capture the experience of nondual awareness. Mindfulness, 10(1), 15-25. https://doi.org/10.1007/s12671-018-0995-z.

Krägeloh, C. U., Henning, M. A., Medvedev, O. N., Feng, X. J., Moir, F., Billington, R., \& Siegert, R. J. (2019). Mindfulness-based intervention research: characteristics, approaches, and developments. Routledge.

Krauss, C. R. (2017). Back to the origins of the repudiation of Wundt: Oswald Külpe and Richard Avenarius. Journal of the History of the Behavioral Sciences, 53(1), 28-47. https://doi.org/10.1002/jhbs. 21833.

Külpe, O. (1893). Grundriss der Psychologie. Auf experimenteller Grundlage dargestellt [Outline of psychology. Illustrated on experimental grounds]. Retrieved from https://archive.org/details/ grundrissderpsyc00kl . Accessed 4 May 2020.

Lundh, L.-G. (2018). Psychological science within a three-dimensional ontology. Integrative Psychological and Behavioral Science, 52, 52-66. https://doi.org/10.1007/s12124-017-9412-8.

Lundh, L.-G. (2019). Experimental phenomenology in mindfulness research. Mindfulness. https://doi.org/10.1007/s12671-019-01274-9.

Sayrak, I. O. (2019). Mindfulness beyond self-help: the context of virtue, concentration, and wisdom. Journal of Communication and Religion, 42(4), 28-38.

Wundt, W. (1897). Grundriss der Psychologie ( $2^{\text {nd }}$ ed.) [Outline of psychology]. Retrieved from https://archive.org/details/ GrundrissDerPsychologie/mode/2up . Accessed 4 May 2020.

Publisher's Note Springer Nature remains neutral with regard to jurisdictional claims in published maps and institutional affiliations. 